\title{
Accelerated Weathering Increases the Release of Toxic Leachates from Microplastic Particles as Demonstrated through Altered Toxicity to the Green Algae Raphidocelis subcapitata
}

\author{
Márta Simon ${ }^{1, *(\mathbb{D}, \text { Nanna B. Hartmann }}{ }^{2}$ and Jes Vollertsen ${ }^{1}$ \\ 1 Department of the Built Environment, Aalborg University, Thomas Manns vej 23, 9220 Aalborg, Denmark; \\ jesvollertsen@build.aau.dk \\ 2 Department of Environmental Engineering, Technical University of Denmark, Bygningstorvet 115, \\ 2800 Kgs. Lyngby, Denmark; nibh@env.dtu.dk \\ * Correspondence: h.marta.simon@gmail.com
}

\section{check for} updates

Citation: Simon, M.; Hartmann, N.B.; Vollertsen, J. Accelerated Weathering Increases the Release of Toxic Leachates from Microplastic Particles as Demonstrated through Altered Toxicity to the Green Algae Raphidocelis subcapitata. Toxics 2021, 9, 185. https://doi.org/10.3390/ toxics 9080185

Academic Editors: Andreu Rico and Roberto Rosal

Received: 2 July 2021

Accepted: 4 August 2021

Published: 5 August 2021

Publisher's Note: MDPI stays neutral with regard to jurisdictional claims in published maps and institutional affiliations.

Copyright: (c) 2021 by the authors. Licensee MDPI, Basel, Switzerland. This article is an open access article distributed under the terms and conditions of the Creative Commons Attribution (CC BY) license (https:/ / creativecommons.org/licenses/by/ $4.0 /)$.

\begin{abstract}
Studies that evaluate the impact of microplastic particles (MPs) often apply particles of pristine material. However, MPs are affected by various abiotic and biotic processes in the environment that possibly modify their physical and chemical characteristics, which might then result in their altered toxic effect. This study evaluated the consequence of weathering on the release of toxic leachates from microplastics. MPs derived from six marine antifouling paints, end-of-life tires, and unplasticised PVC were exposed to UV-C radiation to simulate weathering. Non-weathered and weathered MPs were leached in algae growth medium for $72 \mathrm{~h}$ to demonstrate additive release under freshwater conditions. The model organism, green algae Raphidocelis subcapitata, was exposed to the resulting leachates of both non-weathered and weathered MPs. The results of the growth inhibition tests showed that the leachates of weathered microparticles were more toxic than of the non-weathered material, which was reflected in their lower median effect concentration $\left(\mathrm{EC}_{50}\right)$ values. Chemical analysis of the leachates revealed that the concentration of heavy metals was several times higher in the leachates of the weathered MPs compared to the non-weathered ones, which likely contributed to the increased toxicity. Our findings suggest including weathered microplastic particles in exposure studies due to their probably differing impact on biota from MPs of pristine materials.
\end{abstract}

Keywords: microplastic; weathering; Raphidocelis subcapitata; ecotoxicity

\section{Introduction}

Microplastic pollution is perceived as a threat to the environment that potentially affects organisms at several trophic levels because of the particles' small size [1]. Therefore, the recognition of the ubiquitous presence of microplastic particles (MPs) in the environment during the past decade has raised scientific and public concerns $[2,3]$. Microplastic is an umbrella term for particles measuring up to a few millimetres in their longest diameter, consisting of synthetic polymers or chemically modified natural materials, e.g., natural rubber in tires or resins in coating materials [4-6]. MPs encompass plastic particles manufactured in the given size range, termed primary MPs, as well as secondary MPs, which are defined as plastic fragments formed from larger items or surfaces through chemical breakdown processes and physical abrasion $[7,8]$.

MPs' possible biological impact on a wide range of organisms has drawn scientific attention towards these pollutants. For instance, MPs can cause physical harm to organisms by blocking the gastro-intestinal tract or possibly introducing associated toxic compounds to the environment, or directly to the organism upon ingestion, through the leaching of potentially toxic substances $[1,9,10]$.

While the polymers constituting plastic materials are inert, the residues of catalysts and reactants from the production process, as well as additives, e.g., flame-retardants, softeners, 
and antioxidants, can be toxic to various organisms [11-13]. Lithner et al. (2011) [11] ranked plastic materials based on the hazard of their components that can be released during their production or end-of-life phase. However, this list focused on the risks associated with organic additives, while polymers also contain heavy metals and metalloids that can comprise a substantial fraction of the material $[14,15]$. These inorganic compounds containing, for example, lead, cadmium, zinc, and chromium may serve as pigments, biocides, reinforcing agents, or flame-retardants in plastic products [14,16-18]. MPs might serve as vectors for such compounds as they can easily be dispersed in the environment, owing to their small size $[1,10]$. The presence of inorganic substances has been reported in marine plastic litter and associated with the contamination of soil and sediment adjacent to a plastic waste recycling facility or boat maintenance site $[15,17,19]$. Nevertheless, heavy metal pollution from plastic waste has received insufficient scientific attention to date [14,15].

Numerous studies have documented the potential adverse effect of MPs on various organisms [20-25]. Nevertheless, the lack of standard testing protocols addressing the physical and chemical properties and applied concentration of the investigated MPs has led to laboratory investigations of limited ecological relevance [26]. Exposure studies often apply MPs of pristine materials in uniform shape and size in concentrations greatly exceeding their amount detected in various environmental compartments [27,28]. Such experimental designs fail to represent natural conditions that hinder the assessment of the ecological impact of MPs [26-28]. MPs occur in various forms and sizes that environmental forces continuously modify by the weathering of particles' material, which induces changes in their chemical and physical properties $[4,29]$. UV exposure is the principal weathering factor of MPs, which can cause chemical modifications in materials [7,30]. The resulting alterations are indicated by, for instance, the loss of volatile compounds, a weakened polymer structure, and increased hydrophilicity in the exposed layers of the material [30,31]. Several studies have shown that the altered characteristics of the plastic material can influence its impact on and toxicity towards various organisms [4]. Weathering may enhance the mobility of chemically non-bound compounds, create toxic degradation products, or reduce toxicity by degrading hazardous substances or restricting their migration from the bulk of a material [32-36]. Moreover, exposure studies often focus on marine species, which has led to a limited understanding of the effect of MPs on freshwater organisms and ecosystems, despite the latter's crucial ecological role with its direct connection to terrestrial habitats [37-39]. Such environments have been under disproportionately high anthropogenic stress that has resulted in immense biodiversity loss exceeding its decline in the marine environment [39].

The present study aimed to evaluate the impact of microparticle leachates derived from six commercial antifouling paints, end-of-life tires, and unplasticised PVC-materials which often contain a substantial fraction of heavy metals such as biocides, pigments, catalysts, and heat stabilisers [40-42]. Moreover, this study examined the effect of UV radiation through the accelerated weathering of microparticles on leachate toxicity. Thereby, the effects of pristine and weathered MPs were compared to assess the significance of conducting toxicity experiments with environmentally realistic MPs. The model organism investigated in this study was Raphidocelis subcapitata, a freshwater microalga species, to extend the scarce knowledge on the effect of MPs on the freshwater environment.

\section{Materials and Methods}

\subsection{Materials}

We used microparticles of six commercial marine antifouling paints, tire, and unplasticised polyvinylchloride (PVC) for the toxicity tests. The preparation of the paint particles is described in detail by Simon et al. (2021) [43]. Microparticles of five paints containing copper and zinc were mixed; this particle mixture is hereafter referred to as "paint mix." The sixth paint (zinc paint) contained only zinc in the form of zinc oxide and zinc pyrithione. Rubber granulates $(2-6 \mathrm{~mm})$ derived from end-of-life tires, provided by Genan A/S, Denmark, were cryo-grinded with liquid nitrogen using an IKA A11 basic 
analytical mill to produce tire microparticles for the experiments; these are subsequently referred to as "TP." Unplasticised PVC sheets (CV313250) were purchased from Goodfellow and cryo-grinded using the same analytical mill. All four generated microparticle samples were dry-sieved through 500 and $20 \mu \mathrm{m}$ stainless steel meshes to obtain microparticles in the size range of $20-500 \mu \mathrm{m}$. The microparticles of each material were divided into two mass fractions, and one fraction was exposed to UV-C radiation of $253 \mathrm{~nm}$ in a BS-02 irradiation chamber (Opsytech Dr. Gröbel GmbH, Ettlingen, Germany). We evaluated the weathering of the materials in the preliminary tests by examining their Fourier-transform infrared (FTIR) spectra [43]. The zinc paint microparticles were subjected to accelerated weathering for seven days, the paint mix for 14, and the PVC and tire microparticles for 28 days. FTIR spectra of the tire particles could not be collected due to the inherent black carbon content of the material that absorbs the infrared light, resulting in uninterpretable spectra. Consequently, we chose to expose the tire particles to weathering for 28 days, which was the longest exposure time in our experiment.

\subsection{Particle Characterisation}

Particle size was measured as described in Simon et al. (2021) [43]. In brief, a FlowCam ${ }^{\circledR}$ 8000 Series Dynamic Imaging Particle Analyzer (Fluid Imaging Technologies, Inc., Scarborough, MA, USA) and a Stereo Discovery v.8 stereomicroscope (Zeiss GmbH, Oberkochen, Germany) were used to obtain morphological data of the MPs. These techniques allowed for the quantification of particles measuring larger than $12 \mu \mathrm{m}$, both in their length and width, which were defined as the maximum and minimum Feret diameters, respectively.

\subsection{Leaching}

An amount of $300 \mathrm{mg}$ microparticles was leached in $30 \mathrm{~mL}$ ISO 8692:2004 standard [44] algae growth medium resulting in a particle concentration of $10 \mathrm{~g} \mathrm{~L}^{-1}$. The media were prepared using ultrapure water (Merck Millipore, Darmstadt, Germany). The composition of the media is described in the Supplementary Materials (Table S1). The particle-media mixtures were agitated at $200 \mathrm{rpm}$ at $20^{\circ} \mathrm{C}$ in the dark on an orbital shaker. After $72 \mathrm{~h}$ of leaching, the liquid was filtered through a syringe filter with a $0.45 \mu \mathrm{m}$ pore size to remove any microparticles. The UV-weathered TP leachate required an additional filtration step through a filter with a $0.22 \mu \mathrm{m}$ pore size to remove fine particles. The leachates were either applied immediately for the toxicity tests or kept frozen at $-20^{\circ} \mathrm{C}$ until the test. Triplicate blanks were prepared with algae growth medium, agitated under the same conditions as the microparticles, then filtered and kept frozen for a couple of days until toxicity testing.

\subsection{Growth Inhibition Tests}

Toxicity tests were carried out according to Hartmann et al. (2010) [45] with the green algae Raphidocelis subcapitata, using a mini-scale test setup as first described by Arensberg et al. (1995) [46]. R. subcapitata was chosen as the model organism as it is suitable for testing the effect of substances on the growth inhibition of freshwater microalgae according to the OECD (2011) Test No. 201 guideline [47]. In $20 \mathrm{~mL}$ glass vials, $4 \mathrm{~mL}$ of algae suspensions ( $10^{4}$ algae cells $\mathrm{mL}^{-1}$ in the exponential growth phase) was exposed to a range of dilutions of microparticle leachates prepared with the growth media. The tests were conducted at a $\mathrm{pH}$ of 7.6-8.0, with typical control growth rates of 1.4-1.7 day ${ }^{-1}$ during the $48 \mathrm{~h}$ incubation. The test vials were agitated at $200 \mathrm{rpm}$ in a temperature-controlled room $\left(20 \pm 1{ }^{\circ} \mathrm{C}\right)$, enabling mixing and $\mathrm{CO}_{2}$ diffusion. The samples were continuously illuminated with cold fluorescent light in the visible spectrum. Light intensity was $80-105 \mathrm{E} \mathrm{m}^{-2} \mathrm{~s}^{-1}$ in the wavelength range of 400-700 $\mathrm{nm}$ and was measured under the test vessels using an LICOR light meter (modelLI-189) with an attached quantum sensor. Table 1 summarises the tested concentrations of the definitive tests expressed as the percentage of the concentrated leachate. All tests included triplicates of each tested concentration and five replicates of the control sample, which only contained algae and the growth medium. The $\mathrm{pH}$ of the leachates was adjusted with $0.1 \mathrm{M}$ sodium hydroxide to $7.6-8.0$ before the tests. A 
$0.4 \mathrm{~mL}$ sample was taken from each replicate after $48 \mathrm{~h}$ of incubation to extract chlorophyll and to measure its fluorescence, which is proportional to the algal biomass under the experimental conditions [48]. The rate of growth inhibition was calculated, and log-logistic concentration-response curves were fitted to estimate the effect concentration (EC) at $10 \%$, $20 \%$, and $50 \%$ growth inhibition using the drc package [49] of the software RStudio v.1.2.5. Toxicity tests with undiluted triplicate blank leachates were carried out as well to assess the quality of the media after the leachate preparation procedure. Furthermore, the effect concentrations of the single metal of copper, using $\mathrm{CuSO}_{4} .5 \mathrm{H}_{2} \mathrm{O}$, and of zinc, applied as zinc chloride, were assessed similarly.

Table 1. The tested concentrations of the definitive tests expressed as the percentage of the concentrated leachate (\% of concentrated leachate). Non-weathered refers to microparticles not exposed to UV irradiation, while UV-weathered refers to microparticles exposed to UV-C. The tested concentrations of the weathered microparticle leachates were lower than the non-weathered one, as the range-finding tests demonstrated higher toxicity of these to the algae.

\begin{tabular}{|c|c|c|c|c|c|c|c|}
\hline \multicolumn{8}{|c|}{ Concentration ( $\%$ of Concentrated Leachate) } \\
\hline $\begin{array}{c}\text { TP } \\
\text { Non- } \\
\text { Weathered }\end{array}$ & $\begin{array}{c}\text { TP } \\
\text { UV- } \\
\text { Weathered }\end{array}$ & $\begin{array}{l}\text { Paint Mix } \\
\text { Non- } \\
\text { Weathered }\end{array}$ & $\begin{array}{c}\text { Paint Mix } \\
\text { UV- } \\
\text { Weathered }\end{array}$ & $\begin{array}{c}\text { Zinc Paint } \\
\text { Non- } \\
\text { Weathered }\end{array}$ & $\begin{array}{c}\text { Zinc Paint } \\
\text { UV- } \\
\text { Weathered }\end{array}$ & $\begin{array}{c}\text { PVC } \\
\text { Non- } \\
\text { Weathered }\end{array}$ & $\begin{array}{c}\text { PVC } \\
\text { UV- } \\
\text { Weathered }\end{array}$ \\
\hline 100 & 20 & 10 & 1 & 5 & 3.33 & 100 & 6.67 \\
\hline 50 & 10 & 5 & 0.5 & 3.33 & 2.22 & 50 & 3.33 \\
\hline 25 & 5 & 2.5 & 0.25 & 2.22 & 1.48 & 25 & 1.66 \\
\hline 12.5 & 2.5 & 1.25 & 0.125 & 1.48 & 0.99 & 12.5 & 0.83 \\
\hline 6.25 & 1.25 & 0.63 & 0.063 & 0.99 & 0.66 & 6.25 & 0.42 \\
\hline \multirow[t]{2}{*}{3.1} & 0.63 & & & & 0.44 & & 0.21 \\
\hline & & & & & & & 0.1 \\
\hline
\end{tabular}

\subsection{Chemical Analysis}

Cadmium $(\mathrm{Cd})$, chromium $(\mathrm{Cr})$, copper $(\mathrm{Cu})$, lead $(\mathrm{Pb})$, and zinc $(\mathrm{Zn})$ were measured in the concentrated leachates that were applied in the definitive tests and the blank samples, as the preliminary test revealed the presence of these heavy metals in the MP leachates in detectable concentrations. The measurements were carried out on the acidified leachates with an iCap 6000 inductively coupled plasma-optical emission spectrometer from Thermo Scientific using yttrium internal standard as described in Simon et al. (2021) [43].

\section{Results}

\subsection{Particle Size Characteristics}

Figure 1 illustrates the distribution of the length of the MPs applied in the growth inhibition tests. The median length of all weathered microparticles, except the zinc paint, was larger than that of the non-weathered MPs, despite UV exposure being expected to induce particle fragmentation that would have resulted in an increased number of small particles. The underlying reason for such a discrepancy could be that the size of the formed microparticle fragments was beyond the detection limit of the applied instrument and remained hidden from the analysis. A similar pattern was observed regarding the width of the particles demonstrated in Figure S1. 

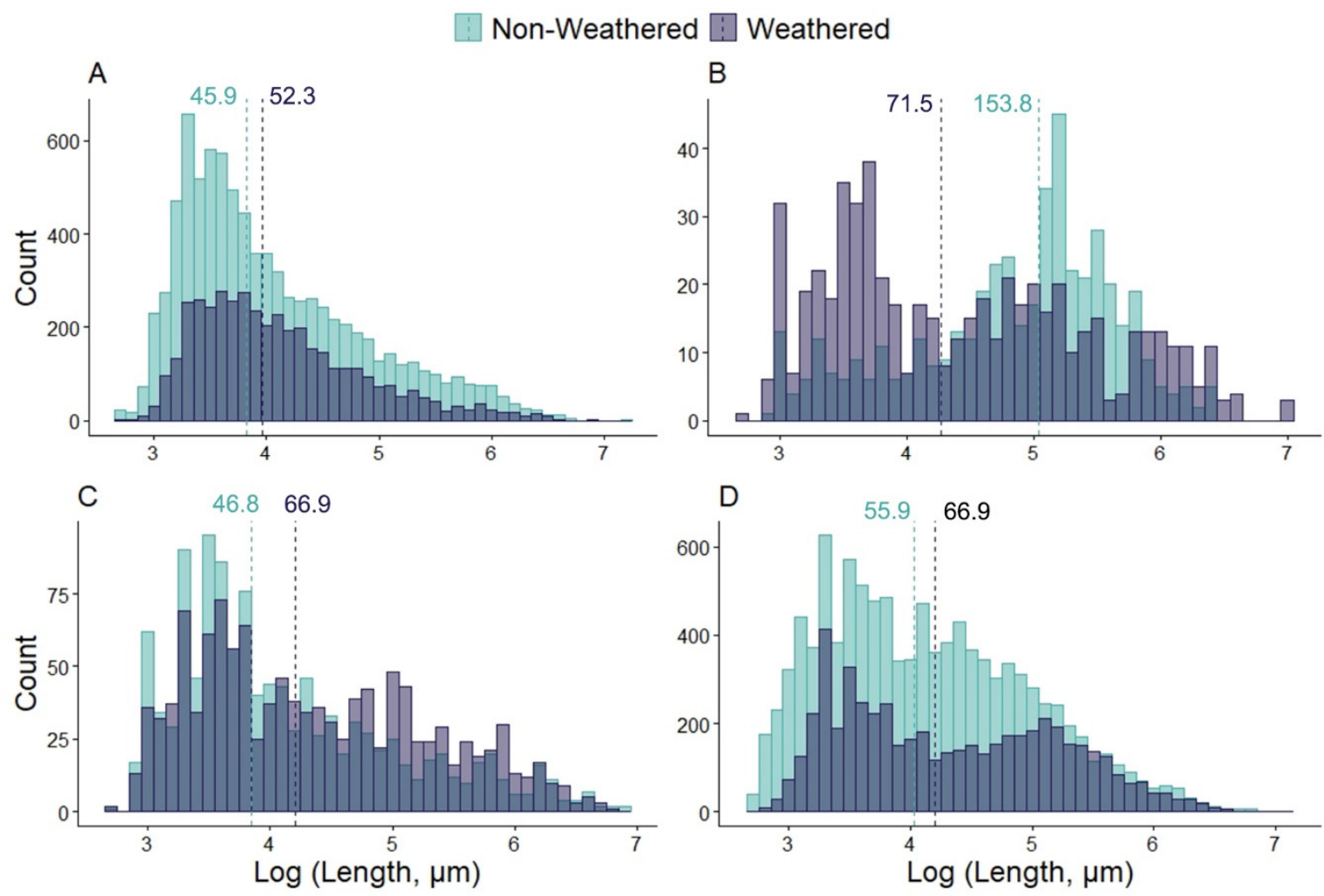

Figure 1. Distribution of the length of non-weathered and weathered paint mix (A), zinc paint (B), tire particle (TP) (C) and PVC (D) microparticles applied in the growth inhibition tests. The size of the bins was 0.1 on a logarithmic scale. The length is defined as the maximum Feret diameter, and the median values in micrometres are denoted.

\subsection{Toxicity of Leachates}

The quality criteria of the growth inhibition tests were fulfilled, since the control growth rate measured between 1.4 and 1.7 day $^{-1}$ and the most considerable $\mathrm{pH}$ change in the controls was 0.9 units, which was well below the accepted 1.5 unit change [44]. Table 2 shows the effect concentrations expressed as the percentage of the concentrated leachate and their $95 \%$ confidence intervals, while the concentration-response curves are found in the Supplementary Materials (Figure S2). All of the tested materials resulted in toxic leachates, and the UV-weathered variants were more toxic than the non-weathered at all toxicity levels. The blank leachates of algae growth media did not affect the growth of the algae (Table S2), meaning that the quality of the growth media did not deteriorate during the leaching procedure and storage. Therefore, it is safe to assume that the observed toxicity of the particle leachates is attributable to the compounds that leached from the MPs. Furthermore, the $\mathrm{EC}_{50}$ of the tested single copper and zinc ions was 32 and $80 \mu \mathrm{g} \mathrm{L}^{-1}$, respectively.

The leachates of the non-weathered paint mix, zinc paint, and tire microparticles exerted similar toxicities at the lower toxic levels, as their $\mathrm{EC}_{10}$ and $\mathrm{EC}_{20}$ values were comparable with overlapping confidence intervals. However, the zinc paint leachate was the most toxic among the non-weathered particles based on the $\mathrm{EC}_{50}$ values, followed by the paint mix, TP, and PVC leachates. The non-weathered PVC leachate was the least toxic among all of the tested materials. 
Table 2. EC values expressed as \% leachate, with the lower and upper confidence intervals of the EC values included. The EC values of single copper and zinc ions are expressed in micrograms per liter.

\begin{tabular}{lcccc}
\hline & & EC $_{\mathbf{1 0}}$ & EC $_{\mathbf{2 0}}$ & \multicolumn{1}{c}{ EC $_{\mathbf{5 0}}$} \\
\hline \multirow{2}{*}{ Non-weathered } & TP & $1.7(1.3-2.1)$ & $2.5(2.1-2.9)$ & $4.7(4.3-5.1)$ \\
& Paint mix & $2.2(1.8-2.6)$ & $2.7(2.3-3.1)$ & $3.9(3.3-4.4)$ \\
& Zinc paint & $1.9(1.8-2.0)$ & $2.1(2.0-2.2)$ & $2.5(2.3-2.6)$ \\
& PVC & $8.8(3.9-13.7)$ & $13.5(8.3-18.8)$ & $28.5(22.7-34.3)$ \\
\hline \multirow{2}{*}{ UV-weathered } & TP & $0.4(0.3-0.5)$ & $0.6(0.5-0.7)$ & $1.2(1.1-1.3)$ \\
& Paint mix & $0.21(0.18-0.24)$ & $0.24(0.22-0.27)$ & $0.3(0.26-0.37)$ \\
& Zinc paint & $0.47(0.41-0.52)$ & $0.54(0.50-0.58)$ & $0.7(0.66-0.73)$ \\
& PVC & $0.21(0.15-0.27)$ & $0.31(0.25-0.38)$ & $0.6(0.54-0.68)$ \\
\hline Zn ion $\left(\mu \mathrm{g} \mathrm{L}^{-1}\right)$ & & $30(15-43)$ & $40(27-57)$ & $80(66-95)$ \\
$\mathrm{Cu}$ ion $\left(\mu \mathrm{g} \mathrm{L}^{-1}\right)$ & & $17(15-19)$ & $21(19-23)$ & $32(22-41)$ \\
\hline
\end{tabular}

The UV-weathered paint mix produced the most toxic leachate among all materials at all toxicity levels. The UV exposure of the PVC particles markedly increased the toxicity of their leachate concerning the non-weathered material. That is, while the PVC leachate was the least toxic at all toxicity levels among the non-weathered particles, the toxicity of the leachates from the UV-weathered PVC particles was similar to that of the leachates from the UV-weathered paint mix and exceeded that of the leachates from the UV-weathered $\mathrm{TP}$ and zinc paint. The toxicity of the leachates from UV-weathered tire and zinc paint microparticles were comparable at lower toxicity levels, but the $\mathrm{EC}_{50}$ of the zinc paint leachate was notably lower.

\subsection{Elemental Composition of MP Leachates}

The leachates of the paint mix microparticles contained zinc and copper in the highest concentrations, while zinc was present in the highest concentration in the leachate of the zinc paint microparticles (Table 3). The TP leachates also contained zinc in the highest concentrations, which likely originates from zinc oxide used as an activator in the vulcanisation process [42]. The leachate of the UV-weathered TP contained chromium, copper, and lead in detectable concentrations as well. The PVC leachate contained lead in the highest concentration, which is a thermal stabiliser added to the polymer as various lead salts $[41,50]$. The concentrations of heavy metals were markedly higher in the leachates of the UV-weathered particles than of the non-weathered material.

Table 3. The blank-corrected concentrations of inorganic elements measured in the concentrated leachates. Total metal refers to the sum of metal concentrations. ND denotes non-detected concentrations.

\begin{tabular}{|c|c|c|c|c|c|c|c|}
\hline & & \multicolumn{6}{|c|}{ Concentration $\left(\mu \mathrm{g} \mathrm{L}^{-1}\right)$} \\
\hline & & $\mathrm{Cd}$ & $\mathrm{Cr}$ & $\mathrm{Cu}$ & $\mathrm{Pb}$ & $\mathrm{Zn}$ & $\begin{array}{c}\text { Total } \\
\text { Metal }\end{array}$ \\
\hline \multirow{4}{*}{$\begin{array}{c}\text { Non- } \\
\text { weathered }\end{array}$} & $\mathrm{TP}$ & ND & ND & ND & ND & 1841 & 1841 \\
\hline & $\begin{array}{l}\text { Paint } \\
\text { mix }\end{array}$ & ND & ND & 78 & 0.48 & 2775 & 2854 \\
\hline & Zn paint & ND & ND & 13 & 0.48 & 956 & 970 \\
\hline & PVC & ND & ND & 2.5 & 113 & 80 & 195 \\
\hline \multirow{4}{*}{$\begin{array}{c}\text { UV- } \\
\text { weathered }\end{array}$} & $\mathrm{TP}$ & ND & 2.18 & 13 & 1.88 & 7187 & 7204 \\
\hline & $\begin{array}{l}\text { Paint } \\
\text { mix }\end{array}$ & ND & ND & 2339 & 3.41 & 23,864 & 26,207 \\
\hline & Zn paint & 1.8 & ND & 3.1 & 1.02 & 7253 & 7259 \\
\hline & PVC & 1.4 & ND & 7.6 & 6630 & 52 & 6691 \\
\hline
\end{tabular}




\section{Discussion}

The tested experimental conditions resulted in $\mathrm{EC}_{50}$ values of all MP leachates. The heavy metals that leached from the microparticles most likely contributed to the toxic effect of the leachates, as they have well-known antimicrobial properties [40,51,52]. Their role in the observed toxicity is highly plausible, as the concentrations of zinc and copper in the undiluted leachates of the paint and tire particles greatly exceeded the $\mathrm{EC}_{50}$ values of 80 and $32 \mu \mathrm{g} \mathrm{L}^{-1}$ obtained in our tests performed with zinc and copper, respectively. The concentration of lead in the PVC leachates was also higher than the $50 \mu \mathrm{g} \mathrm{L}^{-1} \mathrm{EC}_{50}$ of $R$. subcapitata reported by Blinova (2004) [53]. Furthermore, the toxicity of the UV-weathered paint mix and the non-weathered PVC microparticles was consistent with the highest and lowest metal concentrations measured in the undiluted leachates.

However, heavy metal ions were likely not the only components in the leachates that induced toxic effects. That is, the nominal concentration of heavy metals corresponding to the $\mathrm{EC}_{50}$ dilution of the leachate indicates that their concentration was possibly lower than the $\mathrm{EC}_{50}$ of the single metals, except in the case of zinc in the non-exposed TP and paint mix leachate. For example, 3.9\% of the concentrated non-weathered paint mix microparticle leachate caused $50 \%$ growth inhibition, which corresponds to an ion concentration of $3 \mu \mathrm{g} \mathrm{L}^{-1}$ of copper. This estimated concentration is markedly lower than the $\mathrm{EC}_{50}$ value of single copper ions of $32 \mu \mathrm{g} \mathrm{L}^{-1}$ determined in the present study. This is probably because the leachates were complex mixtures of heavy metals and released organic compounds, such as booster biocides, as well as organic components, e.g., additives and degradation products. The latter two can form lipophilic organometallic complexes with the released heavy metals in aqueous media, which increases the bioavailability of the metals [54]. Furthermore, the zinc pyrithione ( $\mathrm{ZnPT}$ ) booster biocide present in the zinc paint could be the cause of the higher toxicity of its microparticle leachate than of the non-weathered TP and paint mix leachate, as the total heavy metal concentration in the zinc paint leachate was distinctly lower. ZnPT is highly toxic to aquatic organisms (e.g., [55,56]) and R. subcapitata, reflected in its low $\mathrm{EC}_{50}$ of $28 \mu \mathrm{g} \mathrm{L}{ }^{-1}$ [57].

Nevertheless, the obtained $\mathrm{EC}_{50}$ values for both the non-weathered and weathered TP leachates ( $1.2 \%$ and $4.7 \%$ leachate, respectively) was comparable to previously reported $\mathrm{EC}_{50}$ values of $R$. subcapitata of $0.5 \%$ and $0.93 \%$ leachate and $0.05-1.01 \mathrm{~g} \mathrm{~L}^{-1}$ particle concentration [58-60].

The UV-weathered paint mix microparticles resulted in the most toxic leachate. This finding is consistent with a previous study, which found that spent antifouling paint particles are toxic to the marine macroalga Ulva lactuta when applied in a few parts per million (ppm) [52]. The $\mathrm{EC}_{50}$ of the UV-weathered PVC leachate was comparable to the $\mathrm{EC}_{50}$ of $1.6 \%$ leachate reported by Capolupo et al. (2020), though the inorganic elemental composition of the two leachates differed. UV-weathered PVC leachate was more toxic than the UV-weathered zinc paint and TP leachates, despite that the total concentration of metals in the PVC, zinc paint, and the TP leachates were comparable.

In summary, the differences in $\mathrm{EC}_{50}$ values indicate that the UV-C weathered MPs rendered more toxic leachates than their non-weathered variants. The increased toxicity is likely partially associated with the higher heavy metal concentrations in the leachates of weathered MPs, which is possibly a consequence of UV-induced changes in the material, resulting in increased metal mobility [43]. Furthermore, co-leached organic substances from the matrix of the paint, tires, and PVC materials could form lipophilic complexes with heavy metals that could increase their bioavailability [40,54].

The results showed that the leachates of marine antifouling paint microparticles were toxic to a freshwater species, even though these materials were intended to prevent the growth of marine organisms. This finding is not surprising, due to the known general antimicrobial effects of zinc and copper, but highlights that further studies on MP ecotoxicological effects, focusing on the freshwater environment, are needed, as MPs can be equally deleterious to both marine and freshwater biota. Furthermore, the outcomes of the present study propose the inclusion of heavy metal controls in MP exposure studies, since MPs can 
contribute to an elevated concentration of these compounds in environmental matrices, as pointed out by Turner (2016) [14]. For instance, soil and sediment contamination has been associated with large plastic items of litter that consist of materials containing a notable fraction of heavy metals, such as the studied antifouling paint, tires, and unplasticised PVC, as well as plastic materials of electronic appliances and so on [14,33,61]. Therefore, investigating heavy metal release and impact on biota is of particular importance in the case of MPs derived from these types of materials.

The experimental design of the present study, namely, MP concentrations exceeding their measured environmental concentrations reported by Burns and Boxall (2018) [27], as well as applying an artificial leaching media, enabled a comparison of the impact of weathering on MP toxicity, as it minimised the effects of possible side reactions during leaching. However, heavy metals released into the aqueous phase undergo dilution and interact with dissolved organic and inorganic matter in the environment. Such interactions include, for example, chelation, complexation, precipitation, and subsequent sedimentation-processes which affect the bioavailability of the metals and the exposure of organisms [40,54]. Although these interactions should be taken into account for a realistic risk assessment of MPs, accounting for them was outside of the scope of the present study, which solely investigated the impact of weathering on MP toxicity.

\section{Conclusions}

The present study evaluated the toxic effect of microparticle leachates derived from various antifouling paint, end-of-life tire, and unplasticised PVC microparticles on a freshwater microalga species, $R$. subcapitata. It pointed to the fact that not only should the possible toxic effect of MPs themselves be considered, but also their potential for release of toxic leachates. Since a combination of particle- and chemically induced effects can be expected under natural conditions, both modes of action should be considered to conduct impact studies with ecological relevance. This approach requires extensive characterisation of MP leaching potential and identification of potentially toxic constituents. Nevertheless, when interpreting the results from such studies, care should be taken to distinguish between particle- and chemically induced effects, as has been recommended for nanomaterial testing [62]. Our results further demonstrated that weathering can significantly enhance the toxic ecological impact of the studied MPs, possibly through mobilising heavy metals in the materials. Consequently, conducting impact studies with weathered MPs might reflect the processes occurring under natural conditions in freshwater ecosystems, as well as potentially in the marine environment, better than MPs of pristine material.

Supplementary Materials: The following are available online at https:/ / www.mdpi.com/article/10 .3390 / toxics9080185/s1, Figure S1: Distribution of the width of non-weathered and weathered microparticles; Figure S2: Concentration-response profiles of particle leachates; Table S1: Composition of the algae growth medium; Table S2: Growth rates of blank samples.

Author Contributions: Conceptualisation, M.S., N.B.H., and J.V.; methodology, M.S. and N.B.H.; formal analysis, M.S.; investigation, M.S.; resources, N.B.H.; writing-original draft preparation, M.S.; writing-review and editing, N.B.H. and J.V.; visualisation, M.S.; supervision, N.B.H.; project administration, J.V.; funding acquisition, J.V. All authors have read and agreed to the published version of the manuscript.

Funding: The study was part of the Marine plastic centre-the Danish centre for research in marine plastic pollution funded by Velux Foundation, Denmark.

Institutional Review Board Statement: Not applicable.

Informed Consent Statement: Not applicable.

Data Availability Statement: Data is available upon request from the corresponding author.

Conflicts of Interest: The authors declare no conflict of interest. 


\section{References}

1. Cole, M.; Lindeque, P.; Halsband, C.; Galloway, T.S. Microplastics as contaminants in the marine environment: A review. Mar. Pollut. Bull. 2011, 62, 2588-2597. [CrossRef] [PubMed]

2. Frias, J.; Nash, R. Microplastics: Finding a consensus on the definition. Mar. Pollut. Bull. 2019, 138, 145-147. [CrossRef]

3. Do Sul, J.A.I.; Costa, M.F. The present and future of microplastic pollution in the marine environment. Environ. Pollut. 2014, 185, 352-364. [CrossRef] [PubMed]

4. Lambert, S.; Scherer, C.; Wagner, M. Ecotoxicity testing of microplastics: Considering the heterogeneity of physicochemical properties. Integr. Environ. Assess. Manag. 2017, 13, 470-475. [CrossRef] [PubMed]

5. Hartmann, N.B.; Hüffer, T.; Thompson, R.C.; Hassellöv, M.; Verschoor, A.; Daugaard, A.E.; Rist, S.; Karlsson, T.M.; Brennholt, N.; Cole, M.; et al. Are We Speaking the Same Language? Recommendations for a Definition and Categorization Framework for Plastic Debris. Environ. Sci. Technol. 2019, 53, 1039-1047. [CrossRef]

6. GESAMP. Sources, Fate and Effects of Microplastics in the Marine Environment-Part Two of a Global Assessment; Kershaw, P.J., Rochman, C.M., Eds.; IMO: London, UK, 2015.

7. Andrady, A.L. Microplastics in the marine environment. Mar. Pollut. Bull. 2011, 62, 1596-1605. [CrossRef]

8. Clark, J.R.; Cole, M.; Lindeque, P.; Fileman, E.; Blackford, J.; Lewis, C.; Lenton, T.M.; Galloway, T.S. Marine microplastic debris: A targeted plan for understanding and quantifying interactions with marine life. Front. Ecol. Environ. 2016, 14, 317-324. [CrossRef]

9. Wright, S.L.; Thompson, R.C.; Galloway, T.S. The physical impacts of microplastics on marine organisms: A review. Environ. Pollut. 2013, 178, 483-492. [CrossRef]

10. Besseling, E.; Wegner, A.; Foekema, E.M.; Heuvel-Greve, M.J.V.D.; Koelmans, A. Effects of Microplastic on Fitness and PCB Bioaccumulation by the Lugworm Arenicola marina (L.). Environ. Sci. Technol. 2013, 47, 593-600. [CrossRef]

11. Hahladakis, J.N.; Velis, C.A.; Weber, R.; Iacovidou, E.; Purnell, P. An overview of chemical additives present in plastics: Migration, release, fate and environmental impact during their use, disposal and recycling. J. Hazard. Mater. 2018, 344, 179-199. [CrossRef]

12. Lithner, D.; Larsson, A.; Dave, G. Environmental and health hazard ranking and assessment of plastic polymers based on chemical composition. Sci. Total. Environ. 2011, 409, 3309-3324. [CrossRef]

13. Hammer, J.; Kraak, M.H.S.; Parsons, J.R. Plastics in the Marine Environment: The Dark Side of a Modern Gift. In Reviews of Environmental Contamination and Toxicology; Springer: New York, NY, USA, 2012. [CrossRef]

14. Hermabessiere, L.; Dehaut, A.; Paul-Pont, I.; Lacroix, C.; Jezequel, R.; Soudant, P.; Duflos, G. Occurrence and effects of plastic additives on marine environments and organisms: A review. Chemosphere 2017, 182, 781-793. [CrossRef]

15. Turner, A. Heavy metals, metalloids and other hazardous elements in marine plastic litter. Mar. Pollut. Bull. 2016, 111, 136-142. [CrossRef] [PubMed]

16. Nakashima, E.; Isobe, A.; Kako, S.; Itai, T.; Takahashi, S. Quantification of Toxic Metals Derived from Macroplastic Litter on Ookushi Beach, Japan. Environ. Sci. Technol. 2012, 46, 10099-10105. [CrossRef]

17. Dimitrakakis, E.; Janz, A.; Bilitewski, B.; Gidarakos, E. Determination of heavy metals and halogens in plastics from electric and electronic waste. Waste Manag. 2009, 29, 2700-2706. [CrossRef] [PubMed]

18. Tang, Z.; Zhang, L.; Huang, Q.; Yang, Y.; Nie, Z.; Cheng, J.; Yang, J.; Wang, Y.; Chai, M. Contamination and risk of heavy metals in soils and sediments from a typical plastic waste recycling area in North China. Ecotoxicol. Environ. Saf. 2015, 122, 343-351. [CrossRef] [PubMed]

19. Ernst, T. Quantification of heavy metals for the recycling of waste plastics from electrotechnical applications. Talanta 2000, 53, 347-357. [CrossRef]

20. Singh, N.; Turner, A. Trace metals in antifouling paint particles and their heterogeneous contamination of coastal sediments. Mar. Pollut. Bull. 2009, 58, 559-564. [CrossRef]

21. Rochman, C.M.; Hoh, E.; Kurobe, T.; Teh, S.J. Ingested plastic transfers hazardous chemicals to fish and induces hepatic stress. Sci. Rep. 2013, 3, 3263. [CrossRef]

22. Bhattacharya, P.; Lin, S.; Turner, J.P.; Ke, P.C. Physical Adsorption of Charged Plastic Nanoparticles Affects Algal Photosynthesis. J. Phys. Chem. C 2010, 114, 16556-16561. [CrossRef]

23. Pannetier, P.; Morin, B.; Le Bihanic, F.; Dubreil, L.; Clérandeau, C.; Chouvellon, F.; Van Arkel, K.; Danion, M.; Cachot, J. Environmental samples of microplastics induce significant toxic effects in fish larvae. Environ. Int. 2020, 134, 105047. [CrossRef]

24. Murphy, F.; Quinn, B. The effects of microplastic on freshwater Hydra attenuata feeding, morphology \& reproduction. Environ. Pollut. 2018, 234, 487-494. [CrossRef] [PubMed]

25. Cole, M.; Lindeque, P.; Fileman, E.; Halsband, C.; Goodhead, R.; Moger, J.; Galloway, T.S. Microplastic Ingestion by Zooplankton. Environ. Sci. Technol. 2013, 47, 6646-6655. [CrossRef]

26. Von Moos, N.; Burkhardt-Holm, P.; Köhler, A. Uptake and Effects of Microplastics on Cells and Tissue of the Blue Mussel Mytilus edulis L. after an Experimental Exposure. Environ. Sci. Technol. 2012, 46, 11327-11335. [CrossRef] [PubMed]

27. De Ruijter, V.N.; Redondo-Hasselerharm, P.E.; Gouin, T.; Koelmans, A.A. Quality Criteria for Microplastic Effect Studies in the Context of Risk Assessment: A Critical Review. Environ. Sci. Technol. 2020, 54, 11692-11705. [CrossRef] [PubMed]

28. Burns, E.E.; Boxall, A.B. Microplastics in the aquatic environment: Evidence for or against adverse impacts and major knowledge gaps. Environ. Toxicol. Chem. 2018, 37, 2776-2796. [CrossRef] 
29. Koelmans, A.A.; Besseling, E.; Foekema, E.; Kooi, M.; Mintenig, S.; Ossendorp, B.C.; Redondo-Hasselerharm, P.E.; Verschoor, A.; Van Wezel, A.P.; Scheffer, M. Risks of Plastic Debris: Unravelling Fact, Opinion, Perception, and Belief. Environ. Sci. Technol. 2017, 51, 11513-11519. [CrossRef]

30. Andrady, A.L. The plastic in microplastics: A review. Mar. Pollut. Bull. 2017, 119, 12-22. [CrossRef]

31. Rabek, J.F. Photostabilization of Polymers: Principles and Application; Elsevier Science Publishers Ltd.: Amsterdam, The Netherlands, 1990. [CrossRef]

32. Wypych, G. Principles of Uv Degradation. In PVC Degradation and Stabilization; ChemTec Publishing: Toronto, ON, Canada, 2015; pp. 167-203. [CrossRef]

33. Bejgarn, S.; MacLeod, M.; Bogdal, C.; Breitholtz, M. Toxicity of leachate from weathering plastics: An exploratory screening study with Nitocra spinipes. Chemosphere 2015, 132, 114-119. [CrossRef]

34. Luo, H.; Li, Y.; Zhao, Y.; Xiang, Y.; He, D.; Pan, X. Effects of accelerated aging on characteristics, leaching, and toxicity of commercial lead chromate pigmented microplastics. Environ. Pollut. 2020, 257, 113475. [CrossRef]

35. Bråte, I.L.N.; Blázquez, M.; Brooks, S.J.; Thomas, K.V. Weathering impacts the uptake of polyethylene microparticles from toothpaste in Mediterranean mussels (M. galloprovincialis). Sci. Total Environ. 2018, 626, 1310-1318. [CrossRef] [PubMed]

36. Rummel, C.D.; Escher, B.I.; Sandblom, O.; Plassmann, M.M.; Arp, H.P.H.; MacLeod, M.; Jahnke, A. Effects of Leachates from UV-Weathered Microplastic in Cell-Based Bioassays. Environ. Sci. Technol. 2019, 53, 9214-9223. [CrossRef] [PubMed]

37. Suhrhoff, T.J.; Scholz-Böttcher, B.M. Qualitative impact of salinity, UV radiation and turbulence on leaching of organic plastic additives from four common plastics-A lab experiment. Mar. Pollut. Bull. 2016, 102, 84-94. [CrossRef]

38. Horton, A.A.; Walton, A.; Spurgeon, D.J.; Lahive, E.; Svendsen, C. Microplastics in freshwater and terrestrial environments: Evaluating the current understanding to identify the knowledge gaps and future research priorities. Sci. Total. Environ. 2017, 586, 127-141. [CrossRef] [PubMed]

39. Lambert, S.; Wagner, M. Freshwater Microplastics: Emerging Environmental Contaminants? Springer: Berlin/Heidelberg, Germany, 2018.

40. Reid, A.J.; Carlson, A.K.; Creed, I.F.; Eliason, E.J.; Gell, P.A.; Johnson, P.T.J.; Kidd, K.A.; MacCormack, T.J.; Olden, J.D.; Ormerod, S.J.; et al. Emerging threats and persistent conservation challenges for freshwater biodiversity. Biol. Rev. 2019, 94, 849-873. [CrossRef]

41. Yebra, D.M.; Kiil, S.; Dam-Johansen, K. Antifouling technology—Past, present and future steps towards efficient and environmentally friendly antifouling coatings. Prog. Org. Coat. 2004, 50, 75-104. [CrossRef]

42. Al-Malack, M.H. Migration of lead from unplasticized polyvinyl chloride pipes. J. Hazard. Mater. 2001, 82, 263-274. [CrossRef]

43. Wik, A.; Dave, G. Environmental labeling of car tires-Toxicity to Daphnia magna can be used as a screening method. Chemosphere 2005, 58, 645-651. [CrossRef]

44. Simon, M.; Vianello, A.; Shashoua, Y.; Vollertsen, J. Accelerated weathering affects the chemical and physical properties of marine antifouling paint microplastics and their identification by ATR-FTIR spectroscopy. Chemosphere 2021, 274, 129749. [CrossRef] [PubMed]

45. International Organization for Standardization [ISO 8692:2004]. Water Quality-Fresh Water Algal Growth Inhibition Test with Unicellular Green Algae; International Organization for Standardization: Geneva, Switzerland, 2004.

46. Hartmann, N.I.B.; von der Kammer, F.; Hofmann, T.; Baalousha, M.; Ottofuelling, S.; Baun, A. Algal testing of titanium dioxide nanoparticles-Testing considerations, inhibitory effects and modification of cadmium bioavailability. Toxicology 2010, 269, 190-197. [CrossRef]

47. Arensberg, P.; Hemmingsen, V.H.; Nyholm, N. A miniscale algal toxicity test. Chemosphere 1995, 30, 2103-2115. [CrossRef]

48. Mayer, P.; Cuhel, R.; Nyholm, N. A simple in vitro fluorescence method for biomass measurements in algal growth inhibition tests. Water Res. 1997, 31, 2525-2531. [CrossRef]

49. Ritz, C.; Baty, F.; Streibig, J.C.; Gerhard, D. Dose-Response Analysis Using R. PLoS ONE 2015, 10, e0146021. [CrossRef]

50. Mizuno, K.; Hirukawa, H.; Kawasaki, O.; Noguchi, H.; Suzuki, O. Development of non-lead stabilized PVC compounds for insulated wires and cables. Furukawa Rev. 1999, 18, 111-118.

51. Turner, A.; Rice, L. Toxicity of tire wear particle leachate to the marine macroalga, Ulva lactuca. Environ. Pollut. 2010, 158, 36503654. [CrossRef] [PubMed]

52. Turner, A.; Pollock, H.; Brown, M.T. Accumulation of $\mathrm{Cu}$ and $\mathrm{Zn}$ from antifouling paint particles by the marine macroalga, Ulva lactuca. Environ. Pollut. 2009, 157, 2314-2319. [CrossRef]

53. Blinova, I. Use of freshwater algae and duckweeds for phytotoxicity testing. Environ. Toxicol. 2004, 19, 425-428. [CrossRef]

54. Holmes, L.; Turner, A. Leaching of hydrophobic $\mathrm{Cu}$ and $\mathrm{Zn}$ from discarded marine antifouling paint residues: Evidence for transchelation of metal pyrithiones. Environ. Pollut. 2009, 157, 3440-3444. [CrossRef]

55. Bao, V.W.; Leung, K.M.; Kwok, K.W.; Zhang, A.Q.; Lui, G.C. Synergistic toxic effects of zinc pyrithione and copper to three marine species: Implications on setting appropriate water quality criteria. Mar. Pollut. Bull. 2008, 57, 616-623. [CrossRef]

56. Jung, S.; Bae, J.; Kang, S.; Son, J.; Jeon, J.; Lee, H.; Sidharthan, M.; Ryu, S.; Shin, H. Acute toxicity of organic antifouling biocides to phytoplankton Nitzschia pungens and zooplankton Artemia larvae. Mar. Pollut. Bull. 2017, 124, 811-818. [CrossRef]

57. Madsen, T.; Samsoe-Petersen, L.; Gustavson, K.; Rasmussen, D. Environmental Project Ecotoxicological Assessment of Antifouling Biocides and Nonbiocidal Antifouling Paints. Environ. Proj. 2000, 531, 112. [CrossRef] 
58. Capolupo, M.; Sørensen, L.; Jayasena, K.D.R.; Booth, A.M.; Fabbri, E. Chemical composition and ecotoxicity of plastic and car tire rubber leachates to aquatic organisms. Water Res. 2020, 169, 115270. [CrossRef] [PubMed]

59. Gualtieri, M.; Andrioletti, M.; Vismara, C.; Milani, M.; Camatini, M. Toxicity of tire debris leachates. Environ. Int. 2005, 31, 723-730. [CrossRef] [PubMed]

60. Wik, A.; Nilsson, E.; Källqvist, T.; Tobiesen, A.; Dave, G. Toxicity assessment of sequential leachates of tire powder using a battery of toxicity tests and toxicity identification evaluations. Chemosphere 2009, 77, 922-927. [CrossRef]

61. Morf, L.S.; Tremp, J.; Gloor, R.; Schuppisser, F.; Stengele, M.; Taverna, R. Metals, non-metals and PCB in electrical and electronic waste-Actual levels in Switzerland. Waste Manag. 2007, 27, 1306-1316. [CrossRef] [PubMed]

62. OECD-Organization-for-Economic-Cooperation-and-Development. Draft Guidance Document on Aquatic and Sediment toxicological testing of nanomaterials. In Proceedings of the 2nd WNT Commenting Round, Paris, France, 2019; pp. 1-73. 